\title{
Dynamic party unity: the US Congress in comparative perspective*
}

\author{
TILL WEBER ${ }^{1 * *}$ AND CRAIG PARSONS ${ }^{2}$ \\ ${ }^{1}$ Baruch College, City University of New York, USA \\ ${ }^{2}$ Department of Political Science, University of Oregon, Eugene, OR, USA
}

\begin{abstract}
Moises Ostrogorski once denounced political parties for burying diverse concerns of pluralistic societies under monolithic electoral options. E.E. Schattschneider celebrated them for the same reason: organizing choice and 'responsible party government' amid pluralistic complexity. Comparativists have found both dynamics in European legislatures: most European parties exhibit the high average levels of voting unity that Schattschneider's theory implies, but also display rather Ostrogorskian cycles of discipline, stifling dissent on divisive issues at election time. We use comparativists' tools to explore the dynamics and normative quality of party unity in the different terrain of the US Congress. We find similar cycles of unity in roll-call voting, but in the American context - with more loosely organized parties, especially historically but still today - Ostrogorskian stifling of dissent operates against a less Schattschneiderian background. In comparative perspective, Congressional parties muffle divisive issues more effectively than they deliver governance, with tenuous implications for representation.
\end{abstract}

Keywords: comparative legislatures; party discipline; representation; roll-call voting

\section{Introduction}

What good or bad effects do strong political parties exert in electoral representation? One scholarly tradition, elaborated mainly by observers from Europe where parties became quite strong, emphasizes the bad. For Roberto Michels and especially Moises Ostrogorski, parties are bad because they distort representation, smothering bottom-up voices in oligarchic domination (Ostrogorski, 1902; Michels, 1915). Parties 'arrange opinions in fixed and rigid grooves' and 'demand the whole citizen' in ways ill-fitted to pluralistic societies (Ostrogorski, 1902: 615). ${ }^{1}$ By prioritizing mobilization around certain causes, Ostrogorski complained, parties stifle cross-cutting concerns. Another tradition, originating in the United States where parties were historically weak, emphasizes the good. For E.E. Schattschneider, strong parties are good because they structure representation, assembling coherent public

\footnotetext{
* Earlier versions were presented at the MPSA meetings of 2010 and 2012, and in the comparative politics colloquium at Humboldt University of Berlin.

1 Ostrogorski used the past tense ('arranged', 'demanded').

** E-mail: till.weber@baruch.cuny.edu
} 
debate amid pluralist complexity. Democracy is 'unthinkable save in terms of the parties' that deliver 'responsible party government', wherein governments stand or fall as citizens choose party platforms (Schattschneider, 1942: 1).

Whether Schattschneiderian or Ostrogorskian effects prevail in any polity should matter for students of democracy, but addressing such normative debates empirically is complex. These views presumably reflect trade-offs more than distinct scenarios: strong parties might deliver coherence and stifle openness. Moreover, apparent party strength has many sources. Coherent parties that focus on certain issues while excluding others might just reflect polarization in societal cleavages. Institutional features like electoral laws might select for or against cohesive party groupings. To credit or blame party organizations for effects on representation, we must separate out the most distinct 'party effects' from overlapping mechanisms.

This article highlights legislative party effects in the American case that speak to Ostrogorkian or Schattschneiderian dynamics in representation. To find such effects, we combine methodological innovations in European parliamentary scholarship with insights from American Congressional literature. In recent years, Europe-focused scholars discovered cycles in parliamentary voting, with parties extremely unified around elections but relatively less at midterm. Short-term variations in unity are most plausibly interpreted as party organizational effects, not as derivatives of extra-parliamentary cleavages or institutions, because these underlying sources of unity rarely change so rapidly. By transposing the European analysis of dynamic unity into the US arena, we sharpen its focus and strengthen its potential implications. Given old skepticism about parties' importance in the US Congress, Americanists have developed sophisticated theories about party effects that help specify the search for voting cycles. By extending the search to Congressional parties with lower average levels of unity - even today, despite rising unity since the 1980s - we raise the analytic and normative stakes that this approach can address. Whereas European cycles often vary only from near-perfect to very high unity, similar cycling around lower unity in US parties is more likely to affect legislative outcomes and the meaningful quality of representation.

Our findings help connect European and American literatures on legislative behavior that have remained strikingly separate (Martin, 2008), but they are depressing in normative terms. In a quantitative analysis of roll-call voting in both houses of Congress since the New Deal, we show that US parties systematically muffle dissent as elections approach. We control for competing explanations of cyclic patterns, including organizational and policy processes and differences between the houses, both in the paper and in an extensive online Appendix. Together with Europe-focused work, our results hint at a surprisingly general pattern of cycles of unity across democracies. Unfortunately, we conclude that American voting cycles invite a more Ostrogorskian interpretation than do European ones. When parties have very high average coherence, such cycles just smooth out marginal dissent while delivering Schattschneiderian benefits of 'responsible party government'. Voters mostly get what was advertised. Given 
the lower baseline coherence of US parties, especially historically but still today, cycles look rather more sinister. They suggest a disingenuous show of election-time unity without comparable transfer of platforms into policy-making. Parties that are generally less able to deliver Schattschneiderian levels of unity are cyclically able to impose Ostrogorskian muffling of dissent.

\section{Comparative European tools: party discipline and dynamic time}

The first inspirations for this project came from Europe-focused parties literature. Large comparative studies explore how well the 'responsible party model' fits European cases (Miller et al., 1999; Schmitt and Thomassen, 1999) and generally report two findings. One is that European parties represent left-right concerns reasonably well, offering voters choices between distinct platforms and transforming platforms into policy. As Thomassen and Schmitt summarized, ‘... the European system of political representation is not in such bad shape as long as we apply it to the basic left-right dimension capable of reflecting the cleavage structure of most European countries' (1999a: 258). The other finding, as their phrasing hints, is problematic representation on other issues, where 'congruence' between parties' positions and their voters' views approaches a random distribution (Pierce, 1999). The most distressing example in recent years is national-level contestation over the European Union. Experts generally agree that mainstream parties have long neglected, avoided, or suppressed debates about EU authority (Van der Eijk and Franklin, 1996, 2004; Hix and Lord, 1997; Mair, 2000; Johansson and Raunio, 2001; Aylott, 2002; De Vreese et al., 2006). They also argue that the key reason is Ostrogorskian: elite and voter positions on these questions cross-cut right- and left-based parties and coalitions, encouraging parties to 'muffle' the divisive issue (Parsons and Weber, 2011).

Comparativists stress that responsible party government requires party unity (Pierce, 1999: 9; Thomassen and Schmitt, 1999b: 15), but that not all unity supports the model. Early on, Ozbudun (1970) noted the difference between party cohesion - built on pre-parliamentary agreement - and party discipline, which is manufactured in parliament and implies some disunity in underlying views. The responsible party model functions best when unity reflects cohesion. The more that unity reflects disciplined dissent, the more it serves to 'muffle' cross-cutting concerns rather than to deliver representation on that issue. Scholars then realized that short-term dynamics could highlight this distinction empirically: underlying cohesion presumably shifts slowly, so short-term fluctuations in unity suggest discipline at work. And on the simple hypothesis that visible dissent should be costliest for parties as elections approach, encouraging leaders to discipline legislators more tightly - or, equally distinct from underlying cohesion, if legislators 'self-discipline' to present a unified electoral front or to optimize bargaining power for coalition negotiations (cf. Laver and Shepsle, 1999) - comparativists began seeking cyclical patterns across electoral terms. In the House of Commons, 
Mughan (1990) found that governing-party unity decreases with midterm troughs in popularity and increases with seat losses in by-elections (when legislators 'rally round the party flag'). Skjaeveland (1999) documents the full cycle in Denmark's Folketing, showing that unity is high after elections, decreasing toward midterm, and rising again as elections approach. Traber et al. (2014) find similar patterns in Switzerland's Nationalrat. Even in the supranational European Parliament, election proximity increases unity of national parties at the expense of European party groups (Lindstädt et al., 2011). In a Europe-wide, mixed-methods study, Parsons and Weber (2011) show that intra-party dissent over the EU is 'muffled' as elections approach. They see these cycles explicitly as Ostrogorskian attempts to exclude a disruptive issue from elections.

Thus, literature on European parties suggests both some Schattschneiderian features of responsible party government and some Ostrogorskian suppression of divisive issues. Methodologically, it offers intriguing tools to highlight variations in dissent that most plausibly flow from party organizations rather than from underlying conditions. We employ these same tools, but see opportunities to sharpen them. First, most of these studies do not distinguish dissent by issue area, which is crucial to our normative questions. Traber et al. (2014) find a more pronounced cycle for salient issues but do not track particular issues. Parsons and Weber (2011) address multiple issues, but we rely on expert survey measures of EU issue intraparty dissent rather than directly on legislative behavior. Second, coding dissent by years, as all these studies do, measures timing crudely relative to elections. Lastly, none of these studies extensively addresses competing explanations of cyclical patterns.

The next two sections explain that a transatlantic extension of this approach is intriguing because it seems counterintuitive. Despite rising party unity, Congress still constitutes a 'hard case' with relatively low average unity and prevailing scholarly views that party effects remain modest. As a result, Congressional scholars have engaged a clash of competing explanations for unity that can help distinguish party-driven cycles from other patterns. Extension to the US case may thus make the cyclical European approach more substantively surprising, analytically sharp, and normatively significant.

\section{American opportunities (I): still a hard case for disciplinary cycles}

Recently, Congressional parties have become more unified than ever - though still not like European parties. Until the 1990s, Congressional politics were largely understood as the opposite of strong party government (Mayhew, 1974). In an institutional environment of majoritarian elections in single-member districts, combined with a separately-elected executive, classic models of legislative representation emphasized individual candidates and their constituencies (Miller and Stokes, 1963). This changed as the long North-South realignment rearranged party lines, and as reforms in the 1970s gave party leaders resources to incentivize 
discipline (Rohde, 1991; Stonecash, 2006). From a fragmented arena with party scores on the Rice index of voting unity below 70 in the 1950s and 1960s, unity peaked in the 110th Congress (2007-09) at 87.25 for the House of Representatives (84.85 including the Senate). ${ }^{2}$

Yet American party unity remains modest by European standards. One survey of European data from the 1990s found Rice index scores that approached perfection, like mean unity across multiple parties of 99.93 in Denmark, 99.33 in France, 99.25 in the United Kingdom, and 99.06 in Belgium (Depauw and Martin, 2009: 105).

Moreover, the Congressional literature about rising unity places modest emphasis on party-driven dynamics. Some scholars remain skeptical that parties matter at all, attributing rising unity instead to extra-parliamentary developments. This challenge came most forcefully from Keith Krehbiel, who argued that rising unity reflected converging preferences - what Ozbudun called cohesion - rather than action by parties (Krehbiel, 1993). A popular interpretation of this trend is that American society has polarized into 'culture wars' along moral and religious lines (Hunter, 1991). Another interpretation traces rising unity mainly to processes of candidate selection. Society overall might not be polarizing, but increasing capture of primary elections by extreme activists leaves voters with polarized options (Fiorina, 2005). This mechanism is more institutional than societal, but it, too, explains unity in Congress by extra-parliamentary selection of legislators with shared preferences.

Against these skeptics arose two theories that stress 'party effects' within Congress, but in modest and benign ways. For the theory of 'conditional party government' (CPG) (Rohde, 1991; Aldrich and Rohde, 2001) and the theory of parties as cartels (Cox and McCubbins, 1993, 2005), parties serve as Congressional amplifiers of extra-Congressional cohesion, not as distinct manufacturers of unity. CPG means that parties' influence is conditional on convergence in legislators' preferences. Given convergent policy goals, legislators delegate power to leaders to manage collective action problems in policy processes. As a result, 'Parties are consequential in shaping members' preferences, the character of the issues on the agenda, the nature of the legislative alternatives, and ultimate political outcomes, and they will remain important as long as the underlying forces that created this partisan resurgence persist' (Rohde, 1991: 192). Cartel theory assigns parties a similar role as in CPG but by different logic. ${ }^{3}$ Legislators who share certain preferences enhance their electoral chances with a party brand that signals their record and agenda. They delegate power to leaders to maintain the brand. Leaders coordinate electoral success to achieve majority control and then use the majority's agenda-setting powers to avoid divisive votes that weaken the brand. Thus both theories suggest some party discipline - as leaders use internal levers or agenda control to lessen dissent on the margins - but within limits. They imply that if

${ }^{2}$ RiceIndex $=\left|\frac{\text { Yeas-Nays }}{\text { Yeas }+ \text { Nays }}\right|$, often multiplied by 100 to range from 0 to 100.

${ }^{3}$ Note that the terminological similarity to Katz and Mair's (1995) 'cartel party' is coincidental. 
leaders managed policy-making or party brands too strongly, stepping beyond amplification of shared goals, legislators would revoke their delegation of power. Almost by definition, parties play a benign Schattschneiderian role: they clarify the translation of convergent preference patterns into governance, but cannot seriously skew those patterns.

Given debates in which even leading advocates of party influence assign them only a modest amplifying role, Congress scholars have not directly asked whether US parties have substantial good or bad effects of their own. Though normative critiques of polarized parties have become common, the salient examples are laments about extra-parliamentary polarization, not Ostrogorskian complaints about party organizations (Fiorina, 2005; Hacker and Pierson, 2005; Rae, 2007). Displaying cyclical unity in this context thus takes 'party effects' debates in new analytic and normative directions. In particular, the less average cohesion a party system displays, the more cyclical voting seems worrisome - suggesting more manufactured, 'muffling'-style unity relative to the cohesion that could sustain responsible party governance.

\section{American opportunities (II): American-made tools to sharpen our analysis}

Though Congress is a novel and counterintuitive context for a search for cyclical unity, the dynamic-time approach speaks directly to methodological challenges in Congressional 'party effects' debates, and their theories help flesh out a dynamictime model and delineate its scope.

In methodological terms, a dynamic-time approach addresses what Smith (2007: 213) characterized as the key challenge in the party-effects literature: that aggregate party effects cannot be cleanly separated from other sources of legislators' preferences. Rather than measuring aggregate levels, we join other studies that highlight party effects through variations in unity that trace most plausibly to party organizational causes (e.g. Snyder and Groseclose, 2000; Cox and Poole, 2002). The more variations in unity operate in the short term, the more plausibly they reflect organizational dynamics within Congress.

In theoretical terms, although CPG and cartel theory imply that party effects are modest - bounded by underlying preference convergence - their logics can be extrapolated to suggest mechanisms for party-driven voting cycles. Neither school would reject that open divisions tend to be costlier near elections: a number of important campaign resources depend on cohesive legislative appearance, including 'informative party labels' (Snyder and Ting, 2002), 'issue ownership' (Petrocik, 1996), symbolic 'message politics' (Evans, 1991), and support of national lobby groups (Cohen et al., 2008). Both frameworks' analyses then hint at why party effects could be cyclical. In CPG's logic, the mechanism would operate vertically, through party leaders. Legislators seek help coordinating policy processes and delegate power to leaders over committee roles, agenda control, and party funds; leaders use these powers to shift votes of legislators who could divide the party. 
Yet exercising these powers risks provoking rebellion, so leaders use them judiciously - especially as elections approach. In cartel theory, the main mechanism would operate horizontally, through legislators themselves. As party brands affect legislators' re-election chances, they self-discipline more toward election time. Another, more vertical mechanism reflects cartel theory's axiom that legislators delegate powers to leaders for 'negative agenda control'. In principle, cartel theory predicts that this mechanism should eliminate strongly party-splitting votes, at least for majority parties that control the agenda. As Cox and McCubbins (2005: 89) note, however, reality challenges such baseline predictions - divisive votes do reach the floor, even sometimes 'rolling' majority parties (bipartisan coalitions defeating the majority of the majority) - and we can extrapolate their logic into expectations about these exceptions. To the extent party-splitting votes take place, they should be rarer closer to elections, when leaders should control the agenda especially carefully.

Even if Congressional theorists have not generally seen parties as strong enough to warrant our normative questions, then, their theories suggest mechanisms behind any cycles we find. We hypothesize that all three mechanisms generate cyclical party effects - though not all connect equally strongly to our normative concerns. As elections approach, we think it plausible that leaders exert more discipline, legislators self-discipline more, and leaders tighten agenda control. To highlight the clearest evidence for the dynamic-time distinction between discipline and cohesion, however, we focus our model on the first two mechanisms and treat the third as a competing explanation for which we must control. Whereas fluctuations in leaders' leverage or legislators' self-discipline suggest that legislators change how they vote for party reasons - voting one way at one point but another when party-based incentives rise - agenda control only suggests avoidance of divisive votes. This qualifies as 'muffling' of dissent, certainly, but it does not seem as troubling in Ostrogorskian terms as party-driven change in votes; to the extent cyclical unity reflects agenda control, nobody ever votes against their party-less inclinations. ${ }^{4}$ To address normative questions about party effects in a sharp and conservative way, we should seek cyclical patterns in dissent that do not reflect agenda control.

Controlling for agenda control will greatly sharpen our model's focus, as will controlling for more prosaic sources of cycles in policy processes. Early votes might simply favor organizational issues that attract more unity, whereas controversial votes and bipartisan initiatives reach the floor later on, followed by party line confrontation toward the term's end. These alternatives call for a two-stage model: one that considers pre-selection of votes and one that highlights cycles in actual votes. Cycles in voting unity are only significant to the extent that they survive a control for selection effects.

\footnotetext{
${ }^{4}$ Furthermore, Diermeier and Vlaicu (2011) demonstrate formally that Cox and McCubbins-style expectations can be derived from a Krehbiel-style party-less model, assuming that procedural costs motivate majority support for agenda control to prioritize policy objectives.
} 
Having positioned our set of European and American tools, we now craft our model. For clarity of presentation we begin with the second of its two stages. First, we discuss our hypotheses and survey the data and key results. Then we show how these results survive controls for selection effects. The findings support some alternatives - agenda control and policy processes do affect timing - but our core cycles emerge largely unscathed.

\section{Hypotheses}

Our model includes party leaders and legislators. Leaders' main goal is to maintain the party coalition for a legislative program and renew majorities for it, reacting to public opinion and national lobby groups. They hold powers to staff committees, control the legislative agenda, coordinate caucus activities, and administer party funds. Legislators' main goal is to secure means to individual re-election. These may be campaign contributions, policy achievements valued by constituents, or identification with a party 'brand'. Other goals include personal influence within the chamber and good public policy (Fenno, 1973). As these goals are rarely achievable without allies (or are even defined in terms of successful alliance), legislators are generally susceptible to party influence.

Leaders' and legislators' goals overlap but varying constituencies create divergences. To avoid conflict, leaders may trade access to committees, agenda control, and funds against voting loyalty (most recently Jenkins and Monroe, 2012). Yet, payoffs cannot always suffice to maintain unity. Homogenizing legislators' voting can endanger their constituency support, even if more unified parties score more legislative victories and do better electorally over time (Lebo et al., 2007). Importantly, resources to mitigate the dilemma are scarce (Sinclair, 1995). Thus leaders and legislators care when exactly they prioritize unity.

Consider the majority party first. Early in a term, majority leaders try to launch their legislative program. The resources involved in organizing Congress let them strike deals with legislators. However, legislators' roll-call records must please distinct constituencies, so they cannot toe the line forever (cf. Wright and Berkman, 1986; Canes-Wrone et al., 2002; Carson et al., 2010). Toward the middle of the term leaders can accept more dissent. The two stages are linked, trading initial loyalty for voting freedom and practical support afterwards.

Toward Election Day, leaders prioritize building campaign resources, so they return to muffling dissent. Legislators again face loyalty incentives because leaders can support them selectively in campaign activities of 'advertising', 'credit claiming', and 'position taking' (Mayhew, 1974; most recently regarding campaign funding: Barber et al., 2014) and so tailor the broad value of the party brand to particular needs. We thus expect dissent to fall during campaigns. Simultaneously, however, legislators face rising incentives to cater to constituencies as elections approach, so campaign time is when party- and constituency-based incentives compete most directly. 
The downward trend of dissent late in the cycle should thus be somewhat weaker than the initial upward trend - as hinted by findings of less party voting in the second Congressional session (MacRae, 1970; Harmel and Janda, 1982; Patterson and Caldeira, 1988).

Majority status should condition this cycle. Central to CPG theory is that majority leaders' powers increase influence on their caucus (Aldrich and Rohde, 2000). We therefore expect a stronger cycle in the majority party. The minority's cycle should be flatter.

Another condition, closer to the 'self-disciplining' cartel theory logic, falls on the legislators' side. The more diverse a caucus, the more legislators face incentives to vote independently. Yet leaders' legislative and electoral goals do not become less important. Rather than more dissent overall, we expect a sharper cycle in diverse parties. Diversity should reflect electoral performance in the last Congressional election (as distinct from majority status): a party that has won seats must accommodate relatively vulnerable new legislators from competitive constituencies. Simultaneously, electoral success may grant leaders a 'mandate' (Grossback et al., 2006) to enforce a stronger cycle.

Our expectations sum to a basic trend with two interactions:

HYPOTHESIS 1: Dissent is highest around the middle of the Congressional term.

HYPOTHESIS 2: The effect of the Congressional cycle is more pronounced for the majority party.

HYPOTHESIS 3: The effect of the Congressional cycle increases with a party's seat gains in the preceding election.

The Congressional cycle is represented by a variable valued 0 for a vote on the 1st day of Congress and increasing to 1 for a vote on Election Day 2 years later. ${ }^{5}$ To capture the cyclical effect, we also include this variable's squared term. Both are interacted with a dummy for the majority party and a variable measuring the share of seats gained (positive values) or lost (negative values) in the last elections. ${ }^{6}$ Interaction with the simple term dominates the initial course of the cycle until interaction with the squared term takes over as elections approach.

Although our model's main focus concerns dynamic hypotheses, majority status should also introduce differentiation on the term level: dissent should be lower in a party that just won the majority, all else equal. New majority leadership enjoys special resources (positions to fill) and room for maneuver (policies to enact). It trades these goods against legislators' support for the party program (Sinclair, 1977). A party that just lost the majority suffers the reverse effect. Leaders lose

\footnotetext{
${ }^{5}$ We dropped votes between Election Day and the term end (1.7\% of all votes).

${ }^{6}$ Importantly, change of seat share is measured in the preceding election. The direction of causality with dissent is thus clearly defined (which is an advantage over ideological measures of caucus heterogeneity).
} 
powers and are blamed for failure, so dissent should be higher. Our model includes dummies for majority and minority parties in their first term.

HYPOTHESIS 4: Winning the majority decreases dissent, losing the majority increases dissent.

\section{Presidential politics}

Our normative assessment of party influence must recognize that American party politics transcends the parliamentary arena (e.g. Kiewiet and McCubbins, 1991). Given separated legislative and executive branches, we expect two spillovers from presidential politics: electoral and policy.

Electoral spillover implies a 4-year cycle of party discipline superimposed on Congress's 2-year cycle. As Press (1963) argued, presidential campaigns may create coattail effects on party discipline: presidential nominees influence the party agenda by forming broad electoral coalitions (also Gershtenson, 2006, 700f.). Presidential campaigns should decrease intra-party dissent as legislators grab the coattails of straight-ticket voting and leaders enforce discipline around presidential campaign labels. ${ }^{7}$ This argument also implies a full cycle: at midterm, presidential popularity generally decreases and legislators and leaders seek distance from the President. Thus:

HYPOTHESIS 5: Dissent is highest around the middle of the presidential term.

The presidential cycle is operationalized like the Congressional cycle but over 4 years: the variable is 0 for a vote in January before the presidential inauguration and rises to 1 on Election Day 4 years later. Again, we also include the squared term.

Presidential and Congressional cycles obviously operate simultaneously. Multivariate regression can isolate their dynamics, but it is worthwhile to visualize our overall expectations. For the losing/minority party, with a weak Congressional cycle, we should mainly see the presidential cycle. For the winning/majority party, we should see the pattern in Figure 1. In presidential years the cycles compound into deep suppression of dissent. In midterm years, the cycles conflict and the trough flattens out. Dissent peaks in non-election years.

Policy spillover also suggests that presidential cycles may differ across issues. Presidential candidates' incentives to construct broad coalitions should make them especially vulnerable to party-dividing issues. Presidential campaigns should, thus mostly suppress 'critical' dissent in divisive issue areas. Afterwards, however, any divisive issues neglected by an incumbent are often politicized by challengers (Hurley and Hill, 2003: 306). We thus expect disunity to culminate toward midterm. Taken together:

\footnotetext{
${ }^{7}$ Even the party losing the presidential race typically benefits from coattail mobilization around its candidate (cf. Franklin, 1971). Toward midterm this effect disappears until new candidates seek nomination.
} 


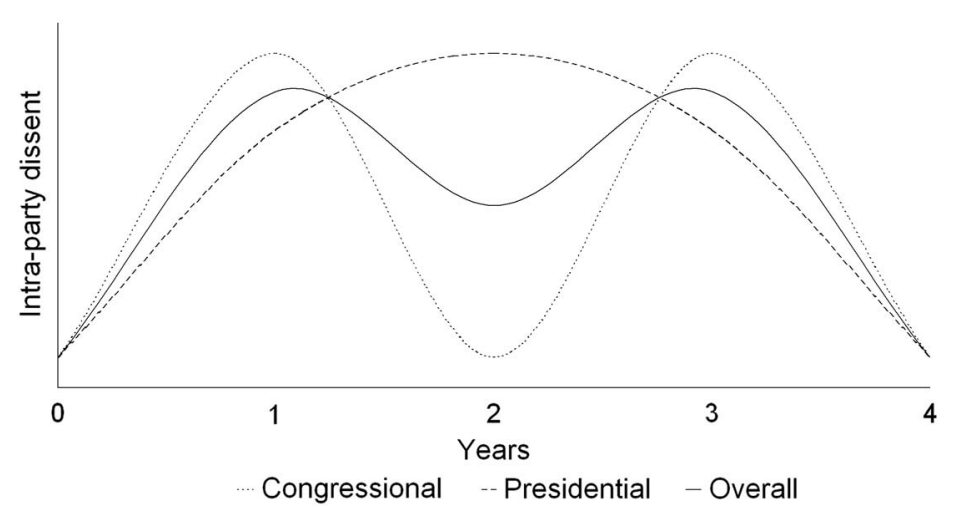

Figure 1 Cycles of intra-party dissent (as expected for winning/majority parties).

HYPOTHESIS 6: The effect of the presidential cycle is more pronounced for divisive issues.

We code issue divisiveness as mean dissent over 2 years in the areas of Clausen's (1973) classification: government management, social welfare, agriculture, civil liberties, foreign/defense policy, and internal organization. ${ }^{8}$ The measure is disaggregated by chamber and party and lagged by one Congress to avoid endogeneity. For example, the issue divisiveness of a social-welfare vote for House Republicans in the 93rd Congress is the mean Republican dissent across all House social-welfare votes in the 92nd Congress. To test whether higher divisiveness implies stronger coattail effects, we interact the divisiveness measure with the two presidential-cycle terms.

The logic of presidential coattails also has term-level implications. A party should be more united if it just won the presidency. The electoral signal of the presidential vote may spill over into the Congressional arena (Sinclair, 1977). We include a dummy for the newly elected president's party and a control for the other party.

HYPOTHESIS 7: Winning the presidency decreases dissent.

\section{Exploring the data}

Our dependent variable is based on the Rice index of unity in roll-call voting. This index cannot directly isolate party effects (Krehbiel, 2000), but - as discussed above - tracing its short-term changes may. To highlight dissent rather than unity, we invert the measure to run continuously from 0 for perfect unity (Yea or Nay) to 1 for an even split. ${ }^{9}$

\footnotetext{
${ }^{8}$ The last category is residual, but coincides with 'internal organization' of the Peltzman (1984) classification in Poole's (2009) data.

9 Thus, Dissent $=1-\left|\frac{\text { Yeas }- \text { Nays }}{\text { Yeas }+ \text { Nays }}\right|$. Each vote is in the data twice, once for the majority party and once for the minority. All votes (not only 'party unity votes') are used to avoid sample bias favoring our hypotheses. We will examine statistically whether lopsided votes affect our results.
} 
Roll-call data are from Poole (2009) for all Congresses from 1933 through 2008. This long period allows us to conduct meaningful tests of all hypotheses including those at Congress or presidency level where the effective $N$ is limited. The starting point is somewhat arbitrary but we choose the New Deal as a major realignment. ${ }^{10}$

The resulting data set involves many votes across time, chambers, parties, and issues. Given this complexity, here we briefly explore the data structure to further nuance our expectations. For this initial exploration, we aggregate intra-party dissent by 2-year Congress in various ways. First, consider the time series shown in Figure 2, which is broken down by chamber and by the six issue areas of Clausen's classification.

One salient feature is generally decreasing dissent since the 1970 s, which may reflect converging preferences, rising party discipline, or both. ${ }^{11}$ Our model captures the long-term trend of dissent with a quadratic polynomial of time.

Also notable is the similarity of House and Senate trends, though the Senate's general level of dissent is higher. The historical developments described in the House-dominated literature on party voting seem to extend to the Senate. Our analysis therefore pools data from both chambers and includes a dummy to account for higher dissent in the Senate. We will also use a flexible estimation strategy to control for remaining cross-chamber differences, and additionally estimate the model separately for each chamber.

Figure 3 presents the development of mean 2-year dissent by party. Here, too, the most striking features are the downward trend and similar patterns across parties. One major and two minor exceptions stand out.

The major exception concerns civil liberties. Here, the Democrats were more divided until the 1970s. This confirms Poole and Rosenthal's (1997) observation that civil rights formed a second dimension that created a North-South split in the Democratic Party. This pattern is even clearer in Poole and Rosenthal's more specific issue classification (not shown): on civil rights, the Democrats often approached an equal split. Beyond race, states' rights also connect to this salient divide, ranking among the five most divisive issue areas (of 107) across our whole period.

Still, civil rights stand out less than we might have expected. Until recently, values close to unity have been rare in general. All issues apparently contain some potential for dissent, making issue divisiveness a matter of degree. Moreover, low covariation across issues hints at multiple underlying sources of conflict. ${ }^{12}$ Our model reflects these patterns through the measure of general issue divisiveness described for Hypothesis 6 above.

\footnotetext{
10 The year 1933 also appeals because the 20th Amendment reorganized terms lengths that year. Differences also occur at later points, with Congressional sessions lengthened and a fiscalyear change in 1976. We explore temporal variation below.

${ }^{11}$ Introduction of roll-call votes in the House's Committee of the whole also had a composition effect (Roberts and Smith, 2003).

12 The average over-time correlation of mean dissent in any two issue areas is 0.54 , meaning that the time series share only $29 \%$ of their variance.
} 


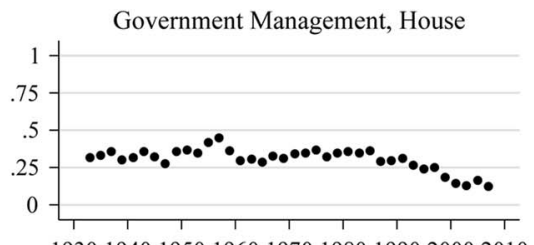

193019401950196019701980199020002010

Social Welfare, House

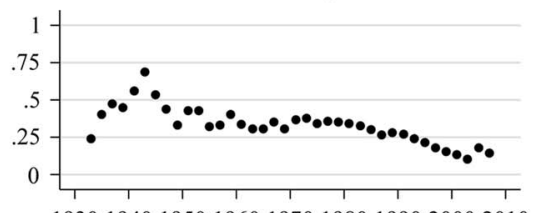

193019401950196019701980199020002010

Agriculture, House

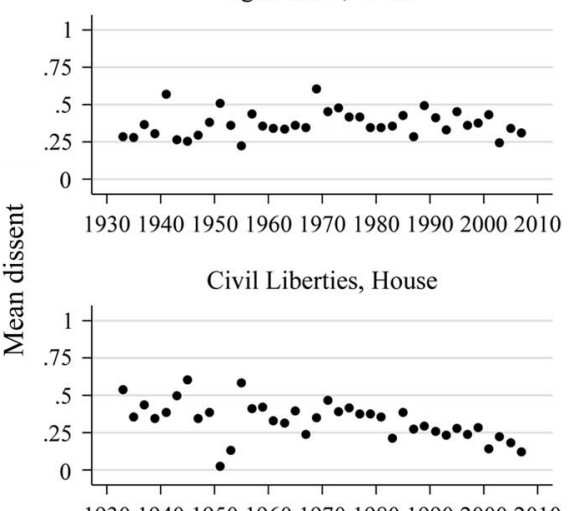

193019401950196019701980199020002010

Foreign and Defense Policy, House

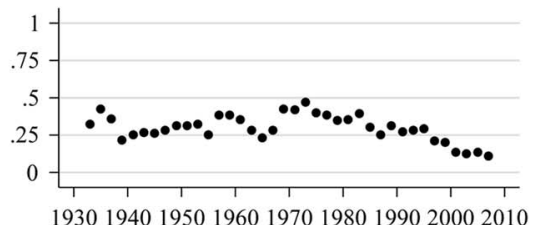

Internal Organization, House

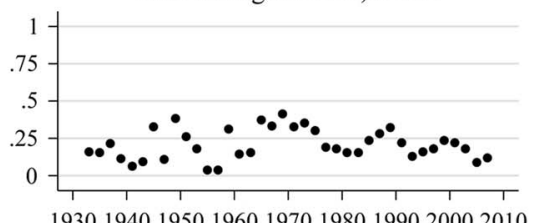

193019401950196019701980199020002010
Government Management, Senate

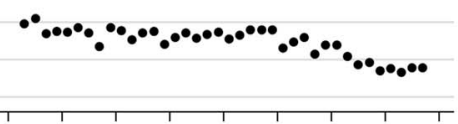

193019401950196019701980199020002010

Social Welfare, Senate

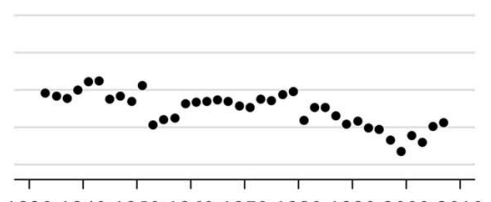

193019401950196019701980199020002010

Agriculture, Senate

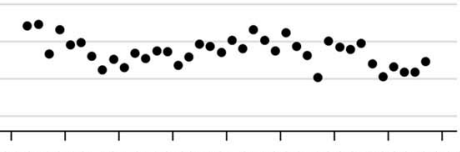

193019401950196019701980199020002010

Civil Liberties, Senate

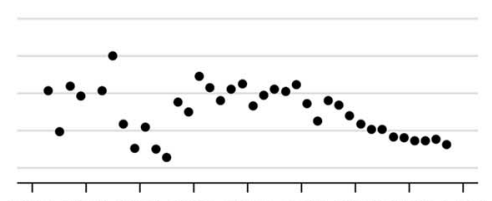

193019401950196019701980199020002010

Foreign and Defense Policy, Senate

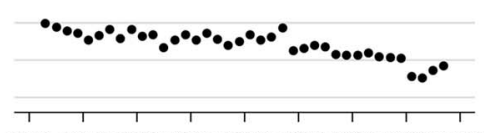

193019401950196019701980199020002010 Internal Organization, Senate

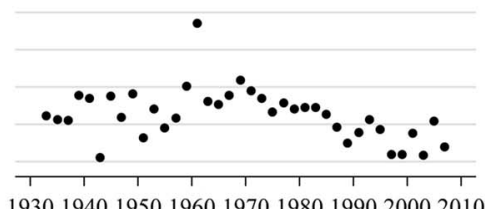

193019401950196019701980199020002010 Year

Figure 2 Mean intra-party dissent over time, by issue area and chamber. 


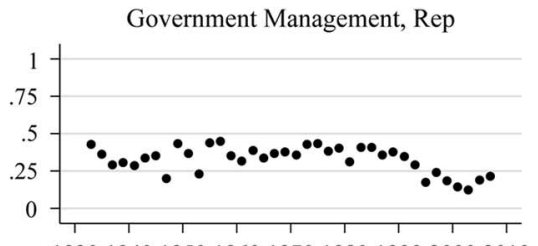

193019401950196019701980199020002010

Social Welfare, Rep

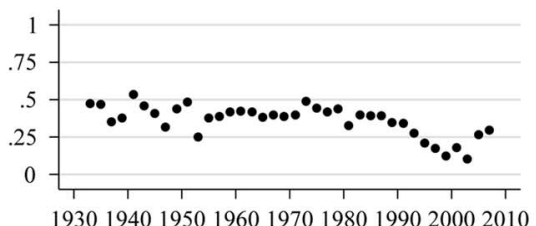

Agriculture, Rep

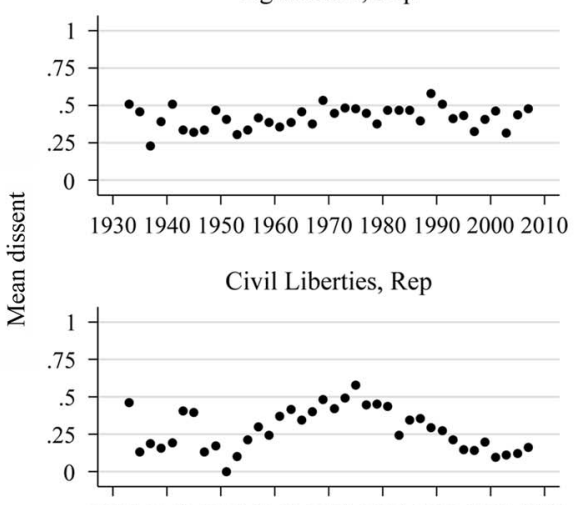

193019401950196019701980199020002010

Foreign and Defense Policy, Rep

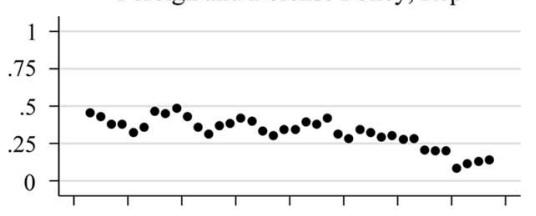

193019401950196019701980199020002010

Internal Organization, Rep

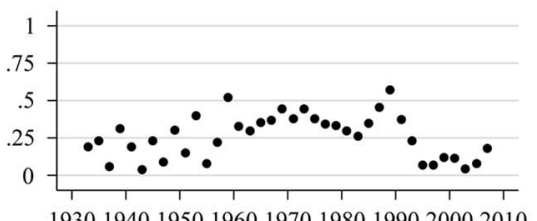

193019401950196019701980199020002010
Government Management, Dem

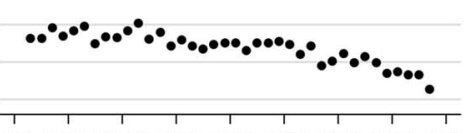

193019401950196019701980199020002010

Social Welfare, Dem

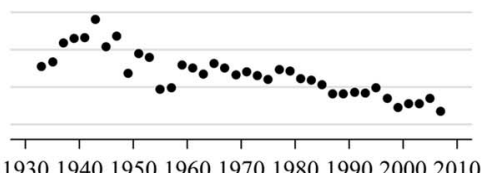

Agriculture, Dem

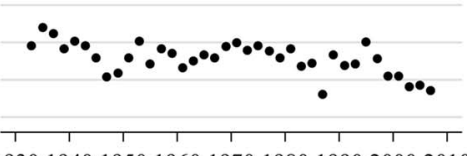

193019401950196019701980199020002010

Civil Liberties, Dem

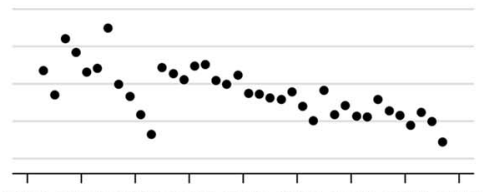

193019401950196019701980199020002010

Foreign and Defense Policy, Dem

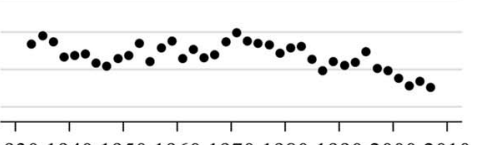

193019401950196019701980199020002010 Internal Organization, Dem

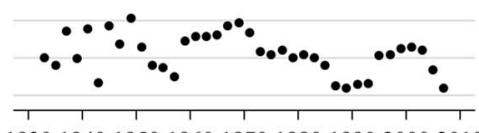

193019401950196019701980199020002010 Year

Figure 3 Mean intra-party dissent over time, by issue area and party. 
A minor exception to similarity across parties concerns 'internal organization', which includes procedural motions and votes on rules governing the floor and committee systems. The two time series of dissent regarding internal organization show breaks coinciding with change of majority control. Republicans became less divided upon gaining control over both chambers in 1994. Simultaneously, Democrats became more divided. The trend reversed when they regained majority control in 2006.

This pattern fits with studies that find stronger party influence in procedural votes (Snyder and Groseclose, 2000; Ansolabehere et al., 2001; Cox and Poole, 2002). With agenda control directly at stake, such votes are often critical for majority leaders. Our model reflects this through an interaction of procedural vote with majority party.

Another minor exception concerns the role of the presidency. The president's party tends to be more divided. Policy coordination with a president seems to put cross-pressure on Congressional allies. In foreign/defense policy, though, this tendency seems to reverse: the president's party generally aligns on the executive (Clausen, 1973). Our model contains an interaction of foreign policy vote with president's party to absorb this effect.

Lastly, we add a party dummy (Democrats) to check that our model captures all systematic party differences. We expect no effect from this variable.

\section{Estimation strategy}

Our dependent variable, intra-party dissent, is a continuous measure that can be estimated by ordinary least squares (OLS) regression. However, the distribution is bounded on both sides - dissent cannot be $<0$ or $>1$ - which entails clustering at lower and upper bounds (18.6 and $0.4 \%$ of the sample; the Appendix includes a histogram). This makes OLS inconsistent and yields predicted values outside the possible range (Wooldridge, 2002, 524f.). The remedy is two-limit tobit regression, which interprets values at the extremes of the range as 'censored' by the inability of our statistical measure to fall below complete unity or surpass an equal split. Left-censored values are treated as ' 0 or less', right-censored values as ' 1 or more'. The model parameters are obtained by maximum likelihood estimation (Tobin, 1958).

In the Appendix, we discuss alternative estimators and demonstrate robustness of our findings to model choice. This also includes a random coefficients model that accounts explicitly for the multilevel data structure.

A final statistical concern is dependence over time. Turnover of legislators is low given incumbency advantages and Senators' long terms. Intra-party dissent is therefore quite persistent, and serial correlation of party voting across Congresses is a perennial concern (Patterson and Caldeira, 1988; Hurley and Wilson, 1989). Fortunately, our model already reflects this: including the issue divisiveness variable 
(i.e. lagged mean dissent by issue area) effectively produces a grouped movingaverage model that handles serial correlation in a theoretically meaningful way.

\section{Results}

Table 1 shows the tobit estimates. As censoring renders the dependent variable deficient, the tobit transformation replaces it by a latent variable that depends linearly on the vector of predictors; it represents pure dissent purged of bias inherent in the indicator of party voting. With regard to this construct, the reported coefficients can be interpreted in OLS fashion, as effects of a one-unit change of an independent variable.

Our Congressional variables display the expected trend of intra-party dissent through the 2-year term: dissent is low early on, increases for over a year, and decreases again toward Election Day. However, the effects in Table 1 must be interpreted carefully because the cycle variables are interacted with majority status and change of seat share. Figure 4 displays the model predictions of dissent through the cycle at different values of the interacting variables. ${ }^{13}$ The curves are predicted levels of dissent; shades of gray indicate significance levels of the marginal effect (whether dissent changes significantly over time at each point). Our hypotheses predict significantly increasing dissent in the first half of a cycle, significantly decreasing dissent in the second half, and, by implication, insignificant change around the midterm reversal point.

Figure 4a confirms our modeling of majority and minority cycles of dissent. The minority party suffers modestly rising dissent in the first half of the cycle and little decrease afterwards. The majority party fluctuates more, uniting more than the minority early and late but actually less in between. Majority power seems to help leaders discipline the party over time. The effect is substantial: a difference in the (inverted) Rice index of 0.11 means that the average majority party in our data loses more than 14 Representatives or more than three Senators in the average vote over the first session of a Congress. Given baseline dissent of 28 Representatives or seven Senators, and the fact that votes are unevenly affected by dissent (see the leftward-biased distribution in the Appendix), this disintegration can easily result in defeat on the floor.

Figure $4 \mathrm{~b}$ supports similar conclusions, displaying how the cyclical effect increases with performance in the preceding election. For losing parties, dissent is largely constant through the term. A stable election result features the first traces of a cyclical effect that is then amplified by each newly won seat. However, winning parties also show generally higher dissent after about 4 months. Thus, two mechanisms indeed seem to underlie the effect of electoral performance. First, a winning party is more diverse. On average its legislators value freedom to

13 Estimates and their standard errors are based on 10,000 simulations drawn from the multivariate normal distribution of the estimated coefficient vector and variance-covariance matrix. Non-interacting variables were held at their means. 
Table 1. Estimation of intra-party dissent in roll-call voting, 1933-2008

\begin{tabular}{|c|c|c|}
\hline Estimator & Two-limit tobit & + Heckman selection \\
\hline \multicolumn{3}{|l|}{ Congressional politics } \\
\hline 2-year cycle & $0.175(0.046) * *$ & $-0.025(0.050)$ \\
\hline 2-year cycle $\times 2$-year cycle & $-0.138(0.041)^{* * *}$ & $0.020(0.043)$ \\
\hline Majority party & $-0.042(0.020) * *$ & $-0.048(0.021) * *$ \\
\hline 2 -year cycle $\times$ majority party & $0.189(0.071) * * *$ & $0.195(0.066)^{* * *}$ \\
\hline 2 -year cycle $\times 2$-year cycle $\times$ majority party & $-0.163(0.066) * *$ & $-0.169(0.060)^{* * *}$ \\
\hline Change of seat share & $-0.246(0.141)^{*}$ & $-0.265(0.152)^{*}$ \\
\hline 2-year cycle $\times$ change of seat share & $1.602(0.526) * *$ & $1.625(0.539) * * *$ \\
\hline 2 -year cycle $\times 2$-year cycle $\times$ change of seat share & $-1.231(0.492) * *$ & $-1.248(0.498)^{* *}$ \\
\hline Just won majority & $-0.088(0.014) * * *$ & $-0.097(0.022) * * *$ \\
\hline Just lost majority & $0.065(0.017) * * *$ & $0.044(0.023)^{*}$ \\
\hline Procedural vote & $0.009(0.019)$ & $0.072(0.025) * * *$ \\
\hline Majority party $\times$ procedural vote & $-0.057(0.023)^{* *}$ & $-0.065(0.034)^{*}$ \\
\hline \multicolumn{3}{|l|}{ Presidential politics } \\
\hline 4-year cycle & $-0.130(0.101)$ & $-0.148(0.085)^{*}$ \\
\hline 4-year cycle $\times 4$-year cycle & $0.075(0.092)$ & $0.123(0.074) *$ \\
\hline Issue divisiveness & $0.453(0.082) * * *$ & $0.327(0.084) * * *$ \\
\hline 4-year cycle $\times$ issue divisiveness & $0.608(0.303) * *$ & $0.526(0.255)^{* *}$ \\
\hline 4-year cycle $\times 4$-year cycle $\times$ issue divisiveness & $-0.547(0.266)^{* *}$ & $-0.438(0.219) * *$ \\
\hline Just won presidency & $-0.042(0.016) * *$ & $-0.032(0.021)$ \\
\hline Just lost presidency & $-0.005(0.013)$ & $0.011(0.018)$ \\
\hline President's party & $0.038(0.010)^{* * * *}$ & $0.043(0.011)^{* * *}$ \\
\hline Vote on foreign policy & $0.004(0.010)$ & $-0.050(0.018)^{* * *}$ \\
\hline President's party $\times$ vote on foreign policy & $-0.042(0.013) * * *$ & $-0.048(0.017)^{* * *}$ \\
\hline \multicolumn{3}{|l|}{ Control variables } \\
\hline Senate & $0.014(0.008) *$ & 3 E-4 (0.010) \\
\hline Years since 1933 & $0.004(0.001) * * *$ & $0.001(0.001)$ \\
\hline Years since $1933 \times$ years since 1933 & $-8 \mathrm{E}-5(1 \mathrm{E}-5) * * *$ & $-7 \mathrm{E}-5(1 \mathrm{E}-5) * * *$ \\
\hline Democrats & $0.003(0.008)$ & $0.005(0.011)$ \\
\hline Selection parameters (inverse Mills ratios) & & Yes \\
\hline Constant & $0.092(0.031) * * *$ & $0.506(0.065) * *$ \\
\hline \multicolumn{3}{|l|}{ Model performance } \\
\hline Pseudo $R^{2}$ & 0.128 & 0.288 \\
\hline $\mathrm{F}$ & $99 * * *$ & $86 * * *$ \\
\hline Log pseudolikelihood & $-42,149$ & $-34,422$ \\
\hline Akaike information criterion & 84,355 & 68,927 \\
\hline Bayesian information criterion & 84,619 & 69,314 \\
\hline
\end{tabular}

Marginal effects with robust standard errors in parentheses, clustered by caucus term. $N=93,446$ (caucus votes) I 152 (caucus-terms) I 76 (caucus presidencies).

$* P<0.1 ; * P<0.05 ; * * P<0.01$.

pursue their own agendas more highly than in losing parties. Second, leadership is strengthened by the successful election and can even discipline a broader caucus.

In both Figure $4 \mathrm{a}$ and $4 \mathrm{~b}$, the early upward trend of dissent is sharper than the following downward trend. This supports our expectation that legislators' overall 

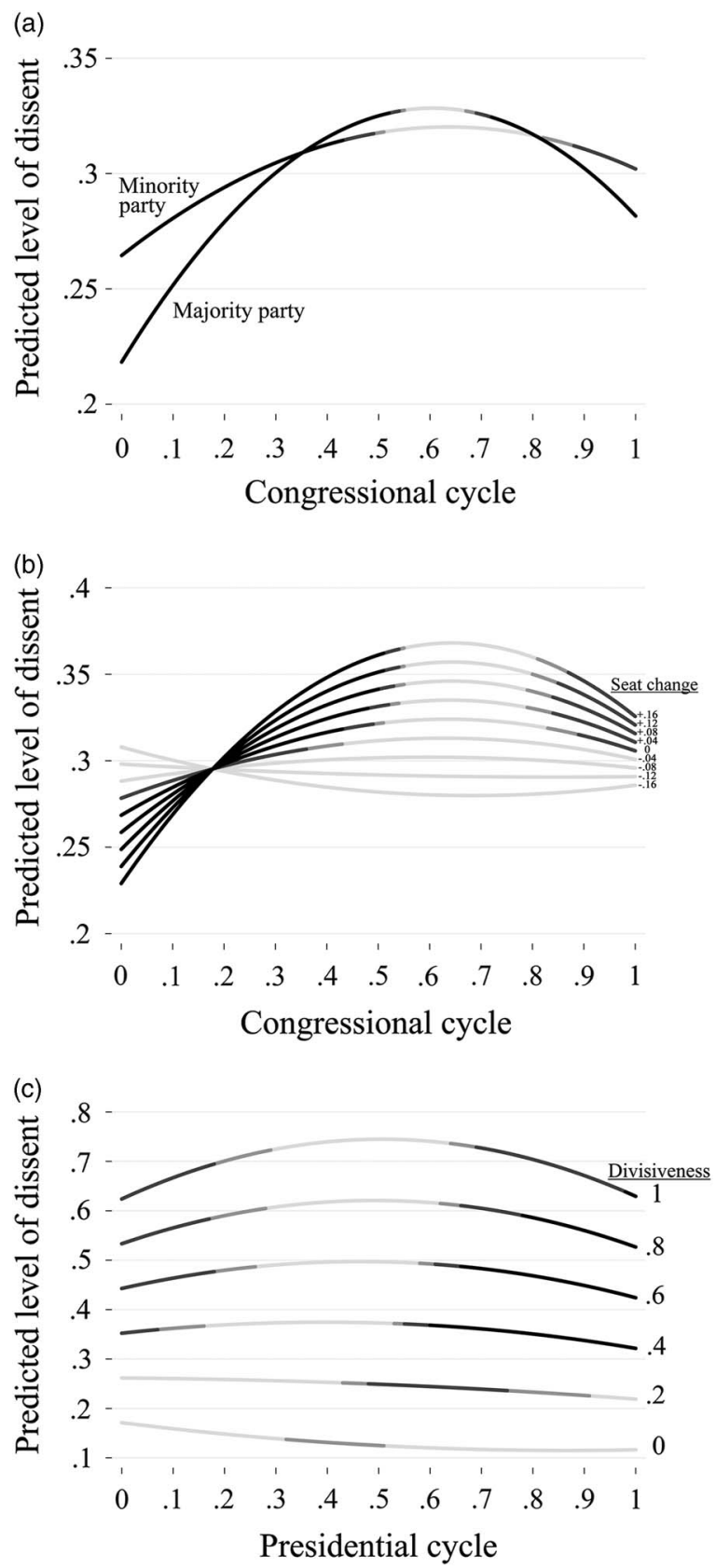

Figure 4 Predictions of intra-party dissent through the electoral cycle. (a) By majority/minority (across the Congressional cycle). (b) By change of seat share (across the Congressional cycle). (c) By issue divisiveness (across the presidential cycle). Curves are predicted levels of intra-party dissent. Shades of gray indicate significance levels of change in dissent over time (the marginal effect of cycle): — black $-99 \%$, _ dark gray $-95 \%, —$ gray $-90 \%$, _ light gray - insignificant. 
incentives for loyalty are strongest right after an election, weakest at midterm, and middling during a campaign, when constituency interests clash with national platforms. Yet the latter, nonetheless, largely prevail and yield a campaign image that is unrepresentative of party unity overall. Landslide-winning and majority parties certainly start strong into the term, but this concerns relatively few votes (see Figure A3 in the Appendix) and soon gives way to prolonged intra-party dissent.

Our remaining Congressional expectations also pan out. New majorities enjoy extra unity, new minorities incur extra dissent. Dissent in procedural votes is lower in the majority party, but not in the minority party. These term-level effects complement our cyclical model.

Turning to presidential variables, we find the expected interaction of the 4-year term with the measure of issue divisiveness. Figure $4 \mathrm{c}$ visualizes the resulting pattern. The first salient finding is regression to the mean: highly divisive issues in one term tend to be relatively less divisive in the next (values on the y-axis diverge less than lagged divisiveness). Leaders usually succeed in restoring order when their caucuses fragment over an issue; in return, they slacken the reins on less critical issues.

In dynamic terms, dissent is low early in the cycle, increases until midterm, and then decreases toward Election Day. As expected, this cycle is stronger for more divisive issues and absent for issues of prevalent unity. When enforcing discipline party leaders indeed seem to prioritize issues that could most threaten the national campaign, and the coattails of the presidential race appear to shift legislators' horizontal incentives toward unity. During presidential campaigns, party unity scores are thus particularly unrepresentative.

Our term-level expectations also find support. A party that just claimed the presidency earns a unity bonus from the coattails. However, overall, the president's party shows higher dissent, except in foreign/defense policy where the interaction term offsets this effect as expected.

Lastly, the control variables behave well. Senate votes feature higher intra-party dissent; the time polynomial captures falling dissent from the 1970s on; and the Democratic dummy's weak and insignificant effect suggests that we have captured all systematic inter-party differences.

\section{Addressing selection effects: agenda control and the policy process}

We now confront possible skepticism that cycles in voting reflect when certain issues come to a vote, not party-induced variation. As we noted earlier, one version of this skepticism follows from cartel theory's emphasis on 'negative agenda control'. We address this possibility by modeling the sequence of the legislative process. Leaders first select which issues to bring to votes at what time, and then may apply pressure on legislators. Two logics might govern the selection stage: absolute unity and relative dissent. In a logic of absolute unity, leaders schedule divisive votes around midterm, when contestation matters least. Thus, what looks like cyclical unity just reflects scheduling of certain votes. In a logic of relative dissent, majority leaders 
target competitors' weaknesses by scheduling votes that divide the minority party more than the majority close to election time. Again the majority would appear to increasingly muffle dissent, but the widening gap would reflect agenda dynamics. ${ }^{14}$

Simpler aspects of policy processes might also shape agenda dynamics. Votes early in the term might favor organizational issues that command greater unity and/ or issues that are consensual across party lines. Once committees begin producing legislation, bipartisan 'problem solving' might lessen party unity around midterm (cf. Adler and Wilkerson, 2013), which then returns as the next campaign approaches and conflictual party line votes are brought to the floor, as well as any backlog of less controversial votes on technical matters and final passage.

Heckman's (1976) selection model can capture such processes statistically. In a first stage it estimates the probability of holding a vote at a certain time. Predictors of this probability (which also satisfy the model's exclusion restriction) operationalize absolute unity, relative dissent, and policy processes as possible origins of agenda dynamics:

- issue area (including the substantive/procedural distinction); ${ }^{15}$

- salience of the vote (CQ's 'key vote' indicator; details in Appendix);

- party differential (difference in dissent between minority and majority);

- lopsidedness (size of winning coalition); and

- partisan conflict (sum of opposed caucus shares).

In the second stage, we then estimate the degree of intra-party dissent as before, but control for the hazard of non-selection in the first stage. This corrects the tobit equation for the omitted variable bias that results from agenda dynamics.

Conventional uses of Heckman models estimate whether an event occurred at all. Our application is original in estimating the timing of events. Adapting work by Dubin and McFadden (1984) and Bourguignon et al. (2007), we estimate a multinomial probit model of the selection stage. The dependent variable has 14 discrete values, one for votes in each quarter year during a 4-year term (cf. footnote 5). From this model we predict the hazard of non-selection (the inverse Mills ratio') for each outcome. These estimates are then added as separate regressors to the final tobit equation. Our model of cyclical dissent, thus controls for the likelihood that votes with certain properties (as defined by the predictors above) are held at particular times during a Congress.

The houses of Congress clearly differ with regard to the two sources of agenda dynamics, majority control and committee procedures. Both these sources were also enduringly affected by reforms in the 1970s (Rohde, 1991). To capture these differences, we allow all effects at the selection stage to vary by chamber and period (pre-/post-1980) using three-way interaction terms.

\footnotetext{
${ }^{14}$ Moreover, such dynamics may not only reflect timing, but also whether a roll-call is requested (cf. Carrubba et al., 2008; Clinton and Lapinski, 2008).

15 Dummies for two issue classifications in Poole's (2009) data: Clausen (1973) mentioned above, and Peltzman (1984) with 13 more functionally defined categories.
} 
The second model of Table 1 shows the estimation results. Agenda dynamics clearly matter, as indicated by a more than doubled pseudo $R^{2}$. The timing of votes across the electoral term is far from random. Still, the selection effect does not interfere substantially with our model. The multinomial Heckman correction leaves coefficients and their significances in the tobit regression largely unaffected, indicating that cyclical patterns are independent of agenda dynamics. A secondary analysis corroborates this. ${ }^{16}$

A closer look at the interactions of Table 1 reveals more telling patterns. Although the majority party still follows a cycle of dissent, the minority's curve - already less concave in Figure $4 \mathrm{a}$ - is now flattened. This is evident in the effect for the minority party, simply indicated by the coefficients of the constitutive terms of the 2-year cycle, which are both weak and insignificant. A similar shift arises for the interaction with seat share change. Here, the weak constitutive effects imply that the curve is flat for parties with stable performance (change of seat share $=0$ ). Winning parties still follow a concave cycle as in Figure $4 \mathrm{~b}$, but losing parties actually follow a reversed (convex) cycle. They are more divided close to election time. This echoes a similar pattern found in European data by Parsons and Weber (2011), which they interpret as the inability of weakened leaders to manage cross-cutting conflicts. Our analysis suggests that this mechanism also operates in the US two-party system, with more direct effects in legislative behavior.

\section{Intriguing non-findings: chamber differences, long-term trends, and issue salience}

Our main empirical goal has been to extend the general model of cyclical party unity to the US Congress. The Appendix also documents and discusses moderate differences between House and Senate, as well as robustness over time and issue salience. These details are striking as non-findings: our model displays cyclical unity even where parties have appeared especially weak, in the Senate and before the 1980s.

\section{Conclusion}

So what? At first glance, the dynamic patterns in Congressional voting reflected by the 'cycle' terms of our main analysis (Table 1) may seem to elaborate CPG or cartel theory without challenging these theories' Schattschneiderian leanings. In amplifying convergence on party-unifying themes around elections - offering voters better-organized choices - parties unavoidably muffle some dissent over

\footnotetext{
16 To further scrutinize agenda dynamics, we tested two models: a logistic regression with a binary dependent variable identifying the top tercile of dissent, and a linear regression with a dependent variable measuring the residual of a regression of dissent on the 0/1 dummy (i.e. what 'remains' of dissent when its 'frequency' is removed). Both regressions (logistic for 'frequency' and linear for 'magnitude') yield similar results to the tobit. This means that dissent is cyclical in its general level, not just in the distribution of extreme cases.
} 
cross-cutting issues. Such costs make representation without parties no less 'inconceivable', in Schattschneider's words, and episodic muffling of secondary issues might be the small downside of sorting pluralistic concerns into electoral choices.

Yet our full findings suggest a more Ostrogorskian interpretation. Responsible party government requires not only that voters choose from coherent platforms but that platforms translate strongly into legislative action. We show that dissent around legislation returns as elections recede, making campaign-time unity partly an electoral show rather than a transmission mechanism for representation. Drawing on CPG and cartel theory, we posit both vertical and horizontal dynamics behind this cycle - leaders enjoy greater leverage around election time, and legislators simultaneously self-discipline to extract all possible value from the party brand - and both mechanisms raise the same normative concern: legislators are voting one way around election time and another later on. The more unity is an election-time façade that is not sustained into policy-making, the less it showcases Schattschneiderian politics.

Although Ostrogorskian fears might seem to originate from party strength, then, they may actually be most troubling where parties are weak. The comparative work that inspired our project shows similar cycles in European parties. Yet these parties presumably offer more Schattschneiderian benefits in return: very high average unity means that they retain considerable coherence even in the cycle's troughs, so that on many issues they translate electoral unity into responsible government. When we find similar cycles in a US context with lower average unity - and especially where parties are weakest, before the 1980s and generally in the Senate unity may be more deceptive. The lower the average unity, the more the cycles' troughs challenge delivery of legislative majorities, and thus the more election-time peaks represent misleading promises to voters. Especially on issues with the highest prevailing levels of dissent, where our analysis finds the strongest cycles (Figure 4c), parties may serve mainly to remove disruptive questions from electoral competition (as with EU issues in Europe: Parsons and Weber, 2011). When overall unity across issues is extremely low - as was long typical in the United States - parties with little capacity to deliver governance might exist largely to construct rhetorical packages and obfuscate cross-cutting concerns. Troublingly, we found the strongest cycles of dissent in parties that should, in principle, be best positioned to deliver on their promises thanks to electoral success and majority control (Figure $4 \mathrm{a}$ and $4 \mathrm{~b}$ ). Certainly, the record of US majority parties in enacting major campaign promises is weak - moments like Obamacare, Newt Gingrich's Contract with America, or Johnson's Great Society are exceptions that prove the rule - and 'weak Ostrogorskian' parties may thus share some of the blame typically attributed to divided government. 'Responsible party government' is especially difficult to deliver in the American context, but unfortunately it seems that Ostrogorskian muffling is somewhat easier to achieve.

We hope that our combination of European and American tools to study party effects and connection of such effects to normative questions encourages others to investigate the quality of party unity in comparative context. In the US case, and 
others, we would applaud steps beyond our focus on voting to study issue framing, committee power, and more technical levers for leadership such as conference reports, omnibus bills or closed rules. Legislators can express dissent in these other processes, not just in floor votes, so other cycles in unity could complement or qualify our results. Outside parliamentary arenas, too, our findings invite attention to effects of fluctuating party unity on the salience and divisiveness of issues in public opinion. Thus a sharpened analytic search for party effects may help us address the normative reasons why we care about political parties.

\section{Acknowledgments}

The authors thank Fabrizio Bernardi, Mark Franklin, David Jones, Eric McGhee, Gregory Robinson, James Stimson, Bernhard Wessels, Christopher Wlezien, and the anonymous reviewers for their helpful comments.

\section{Supplementary material}

To view supplementary material for this article, please visit http://dx.doi.org/ 10.1017/S1755773915000235.

\section{References}

Adler, S. and J. Wilkerson (2013), Congress and the Politics of Problem Solving, Cambridge: Cambridge University Press.

Aldrich, J. and D. Rohde (2000), 'The consequences of party organization in the House: the role of the majority and minority parties in conditional party government', in J. Bond and R. Fleisher (eds) Polarized Politics: Congress and the President in a Partisan Era, Washington, DC: CQ Press, pp. 31-72.

- (2001), 'The logic of conditional party government', in L. Dodd and B. Oppenheimer (eds) Congress Reconsidered, Washington, DC: CQ Press, pp. 269-292.

Ansolabehere, S., J. Snyder Jr. and C. Stewart III (2001), 'The effects of party and preferences on congressional roll-call voting', Legislative Studies Quarterly 26(4): 533-572.

Aylott, N. (2002), 'Let's discuss this later: party responses to euro-division in Scandinavia', Party Politics $8(4): 463-481$.

Barber, M., B. Canes-Wrone and J.-F. Godbout (2014), 'Party loyalty and campaign contributions', European Political Science Association Annual Meeting, June 21, 2014, Edinburgh.

Bourguignon, F., M. Fournier and M. Gurgand (2007), 'Selection bias corrections based on the multinomial logit model: Monte-Carlo comparisons', Journal of Economic Surveys 21(1): 174-205.

Canes-Wrone, B., D. Brady and J. Cogan (2002), 'Out of step, out of office: electoral accountability and House members' voting', American Political Science Review 96(1): 127-140.

Carrubba, C., M. Gabel and S. Hug (2008), 'Legislative voting behavior, seen and unseen: a theory of roll-call vote selection', Legislative Studies Quarterly 33(4): 543-572.

Carson, J., G. Koger, M. Lebo and E. Young (2010), 'The electoral costs of party loyalty in Congress', American Journal of Political Science 54(3): 598-616.

Clausen, A. (1973), How Congressmen Decide: A Policy Focus, New York, NY: St. Martin's Press.

Clinton, J. and J. Lapinski (2008), 'Laws and roll calls in the U.S. Congress, 1891-1994', Legislative Studies Quarterly 33(4): 511-541. 
Cohen, M., D. Karol, H. Noel and J. Zaller (2008), The Party Decides: Presidential Nominations Before and After Reform, Chicago, IL: University of Chicago Press.

Cox, G. and M. McCubbins (1993), Legislative Leviathan. Party Government in the House, Berkeley, CA: University of California Press.

Cox, G. and K. Poole (2002), 'On measuring partisanship in roll-call voting: the U.S. House of Representatives, 1877-1999', American Journal of Political Science 46(3): 477-489.

Cox, G. and M. McCubbins (2005), Setting the Agenda. Responsible Party Government in the U.S. House of Representatives, Cambridge: Cambridge University Press.

Depauw, S. and S. Martin (2009), 'Legislative party discipline and cohesion in comparative perspective', in D. Giannetti and K. Benoit. (eds) Intra-Party Politics and Coalition Governments in Parliamentary Democracies, London: Routledge, pp. 103-120.

De Vreese, C., S. Banducci, H. Semetko and H. Boomgaarden (2006), 'The news coverage of the 2004 European Parliamentary election campaign in 25 countries', European Union Politics 7(4): 477-504.

Diermeier, D. and R. Vlaicu (2011), 'Parties, coalitions, and the internal organization of legislatures', American Political Science Review 105(2): 359-380.

Dubin, J. and D. McFadden (1984), 'An econometric analysis of residential electric appliance holdings and consumption', Econometrica 52(2): 345-362.

Evans, L. (1991), Leadership in Committee: A Comparative Analysis of Leadership Behavior in the U.S. Senate, Ann Arbor, MI: University of Michigan Press.

Fenno, R., Jr. (1973), Congressmen in Committees, Boston, MA: Little Brown.

Fiorina, M. (2005), Culture War? The Myth of a Polarized America, New York, NY: Longman.

Franklin, M. (1971), 'A "non-election" in America? Predicting the results of the 1970 mid-term election for the U.S. House of Representatives', British Journal of Political Science 1(4): 508-513.

Gershtenson, J. (2006), 'Election cycles and partisanship in the U.S. House of Representatives, 1857-2000', Politics \& Policy 34(4): 690-705.

Grossback, L., D. Peterson and J. Stimson (2006), Mandate Politics, Cambridge: Cambridge University Press.

Hacker, J. and P. Pierson (2005), Off Center: The Republican Revolution and the Erosion of American Democracy, New Haven, CT: Yale University Press.

Harmel, R. and K. Janda (1982), Parties and Their Environments: Limits to Reform, New York, NY: Longman.

Heckman, J. (1976), 'The common structure of statistical models of truncation, sample selection, and limited dependent variables and a simple estimator for such models', Annals of Economic and Social Measurement 5(4): 475-492.

Hix, S. and C. Lord (1997), Political Parties in the European Union, New York, NY: Macmillan.

Hunter, J.D. (1991), Culture Wars: The Struggle to Control the Family, Art, Education, Law, and Politics in America, New York, NY: Basic Books.

Hurley, P. and R. Wilson (1989), 'Partisan voting patterns in the U.S. senate, 1877-1986', Legislative Studies Quarterly 14(2): 225-250.

Hurley, P. and K.Q. Hill (2003), 'Beyond the demand-input model: a theory of representational linkages', Journal of Politics 65(2): 304-326.

Jenkins, J. and N. Monroe (2012), 'Buying negative agenda control in the U.S. House', American Journal of Political Science 56(4): 897-912.

Johansson, K.M. and T. Raunio (2001), 'Partisan responses to Europe: comparing Finnish and Swedish political parties', European Journal of Political Research 39(2): 225-249.

Katz, R. and P. Mair (1995), 'Changing models of party organization and party democracy: the emergence of the cartel party', Party Politics 1(1): 5-28.

Kiewiet, R. and M. McCubbins (1991), The Logic of Delegation: Congressional Parties and the Appropriations Process, Chicago, IL: University of Chicago Press.

Krehbiel, K. (1993), 'Where's the party?', British Journal of Political Science 23(2): 235-266.

- (2000), 'Party discipline and measures of partisanship', American Journal of Political Science 44(2): 212-227. 
Laver, M. and K. Shepsle (1999), 'How political parties emerged from the primeval slime: party cohesion, party discipline, and the formation of governments', in S. Bowler, D. Farrell and R. Katz (eds) Party Discipline and Parliamentary Government, Columbus, OH: Ohio State University Press, pp. 23-48.

Lebo, M., A. McGlynn and G. Koger (2007), 'Strategic party government: party influence in Congress, 1789-2000', American Journal of Political Science 51(3): 464-481.

Lindstädt, R., J. Slapin and R. Vander Wielen (2011), 'Balancing competing demands: position taking and election proximity in the European Parliament', Legislative Studies Quarterly 36(1): 37-70.

MacRae, D., Jr. (1970), Issues and Parties in Legislative Voting: Methods of Statistical Analysis, New York, NY: Harper \& Row.

Mair, P. (2000), 'The limited impact of Europe on national party systems', West European Politics 23(4): 27-51.

Martin, S. (2008), 'Two houses: legislative studies and the Atlantic divide', PS: Political Science and Politics 41(3): 557-565.

Mayhew, D. (1974), Congress: The Electoral Connection, New Haven, CT: Yale University Press.

Michels, R. (1915), Political Parties: A Sociological Study of the Oligarchical Tendencies of Modern Democracy, (translated by Eden Paul) New York, NY: Hearst.

Miller, W. and D. Stokes (1963), 'Constituency influence in Congress', American Political Science Review 57(1): 45-56.

Miller, W., R. Pierce, J. Thomassen, R. Herrera, S. Holmberg, P. Esaiasson and B. Wessels (1999), Policy Representation in Western Democracies, Oxford: Oxford University Press.

Mughan, A. (1990), 'Midterm popularity and governing party dissension in the House of Commons, 1959-79', Legislative Studies Quarterly 15(3): 341-356.

Ostrogorski, M. (1902), Democracy and the Organization of Political Parties, (translated By Frederick Clarke) New York, NY: Macmillan.

Ozbudun, E. (1970), Party Cohesion in Western Democracies: A Causal Analysis, Beverly Hills, CA: SAGE.

Parsons, C. and T. Weber (2011), 'Cross-cutting issues and party strategy in the European Union', Comparative Political Studies 44(4): 383-411.

Patterson, S. and G. Caldeira (1988), 'Party voting in the United States Congress', British Journal of Political Science 18(1): 111-131.

Peltzman, S. (1984), 'Constituent interest and congressional voting', Journal of Law and Economics 27(1): 181-210.

Petrocik, J. (1996), 'Issue ownership in presidential elections, with a 1980 case study', American Journal of Political Science 40(3): 825-850.

Pierce, R. (1999), 'Mass-elite issue linkages and the responsible party model of representation', in Miller et al., 1999: 9-32.

Poole, K. (2009), Voteview roll call database. Retrieved 13 January 2010 from http://voteview.com/.

Poole, K. and H. Rosenthal (1997), Congress: A Political-Economic History of Roll Call Voting, New York, NY: Oxford University Press.

Press, C. (1963), 'Presidential coattails and party cohesion', Midwest Journal of Political Science 7(4): 320-335.

Rae, N. (2007), 'Be careful what you wish for: the rise of responsible parties in American national politics', Annual Review of Political Science 10: 179-191.

Roberts, J. and S. Smith (2003), 'Procedural contexts, party strategy, and conditional party voting in the U.S. House of Representatives, 1971-2000', American Journal of Political Science 47(2): 305-317.

Rohde, D. (1991), Parties and Leaders in the Postreform House, Chicago, IL: University of Chicago Press. Schattschneider, E.E. (1942), Party Government, New York, NY: Holt, Rinehart and Winston.

Schmitt, H. and J. Thomassen (eds) (1999), Political Representation and Legitimacy in the European Union, Oxford: Oxford University Press.

Sinclair, B. (1977), 'Determinants of aggregate party cohesion in the U.S. House of Representatives, 1901-1956', Legislative Studies Quarterly 2(2): 155-175.

- (1995), Legislators, Leaders, and Lawmaking: The U.S. House of Representatives in the Postreform Era, Baltimore, MD: Johns Hopkins University Press.

Skjaeveland, A. (1999), 'A Danish party cohesion cycle', Scandinavian Political Studies 22(2): 121-136. 
Smith, S. (2007), Party Influence in Congress, Cambridge: Cambridge University Press.

Snyder, J., Jr. and T. Groseclose (2000), 'Estimating party influence in congressional roll-call voting', American Journal of Political Science 44(2): 193-211.

Snyder, J., Jr. and M. Ting (2002), 'An informational rationale for political parties', American Journal of Political Science 46(1): 90-110.

Stonecash, J. (2006), Political Parties Matter: Realignment and the Return of Partisan Voting, Boulder, CO: Lynne Reinner.

Thomassen, J. and H. Schmitt (1999a), 'In Conclusion', in Schmitt and Thomassen, 1999: 255-267.

- (1999b), 'Introduction', in Schmitt and Thomassen, 1999: 3-21.

Tobin, J. (1958), 'Estimation of relationships for limited dependent variables', Econometrica 26(1): 24-36.

Traber, D., S. Hug and P. Sciarini (2014), 'Party unity in the Swiss parliament: the electoral connection', Journal of Legislative Studies 20(2): 193-215.

Van der Eijk, C. and M. Franklin (eds) (1996), Choosing Europe? The European Electorate and National Politics in the Face of Union, Ann Arbor, MI: University of Michigan Press.

- (2004), 'Potential for contestation on European matters at national elections in Europe', in G. Marks and M. Steenbergen (eds) European Integration and Political Conflict, Cambridge: Cambridge University Press, pp. 32-50.

Wooldridge, J. (2002), Econometric Analysis of Cross Section and Panel Data, Cambridge: MIT Press.

Wright, G., Jr. and M. Berkman (1986), 'Candidates and policy in United States Senate elections', American Political Science Review 80(2): 567-588. 